\title{
Contribuição para o estudo do crescimento de essências do cerrado
}

(Resumo da tese de doutoramento apresentada a E. S. A. "Luiz de Queiroz, em 1953)

O. A. GURGEL FILHO

Engenheiro Agrônomo - Doutor em Agronomia Hôrto Exp. de Sta. Rita do P. Quatro (*)

$O$ autor nesse trabalho visa o estudo do crescimento em altura, de três essências que se desenvolvem nos cerrados de São Simäo, Estado de S. Paulo. As essências consideradas foram : barbatimão Stryphnodendron barbatimāo, Mart.; canafistula Dimorphandra mollis, Benth; e faveiro, Pterodon pubescens, Benth., tôdas pertencentes à família das leguminosas.

$O$ experimento foi realizado no Hôrto Florestal de São Simão, o qual está situado na regiäo noroeste da mesma localidade; a altitude média é dé $635 \mathrm{~m}$ e suas coordenadas geográficas

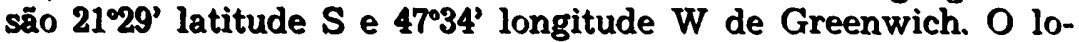
cal onde a esperiência se processou apresentava vegetação típica do cerrado, incluindo entre outras, as espécies que foram objeto do estudo. Os sólos pertencem an Arenito de Botucatú. O tipo climático é o temperado úmido, segundo o sistema brasileiro de Serebrenick. 
O autor, procedendo à revisão bibliográfica, resalta os estudos e conceitos de autores estrangeiros sôbre o crescimento das essências, com a decorrência de idades, as curvas de evolução do crescimento, da taxa do acréscimo, etc.

O esquema experimental seguido foi o dos blócos ao acaso, com 4 repetições complétas. As medições das alturas das plantas, foram efetuadas em dezembro de 1947, outubro de 1949, abril de 1951 e abril de 1953.

Foi efetuada detalhada análise da variância, resultando a infurmação da existência de manchas do terreno, sendo porém as parcelas uniformes; por outro lado, foi constatada a heterogeneidade do material.

A fim de obter a sensibilidade necessária para os cálculos estatísticos, foram feitos agrupamentos naturais de altura para as três essências estudadas. Comprovou-se ainda que as médias dos agrupamentos, não diferiam, estatisticamente, das médias calculadas dirètamente a partir dos dados originais (altu-. ra em 4 épocas distintas).

Finalmente, foram calculadas as correlações lineares entre agrupamentos e as correlações totais. Como consequências resultou a conclusão de que o crescimento das essências estudadas é fortemente correlacionado com a idade, com exceção do primeiro ano; que os acréscimos de períndo para período são correlacionados com o acréscimo do período anterior.

O autor apresenta ainda as curvas de evolução do crescimento em altura, bem como as curvas da taxa do acréscimo, para os diferentes agrupamentos das três essências estudadas, e os quadros com os dados respectivos. Os gráficos além de demonstrarem as respectivas idades que se sucedem no ciclo evolutivo da planta, apresentam a normalidade do crescimento de muitos grupos, conforme a curva sigmoidal. Os gráficos ainda corroboram as conclusões da análise estatística, revelando a existência de correlações no crescimento, desde a idade nova.

Finalmente, o autor apresenta 14 conclusões, sobressaindo como as mais importantes as seguintes: 1) Os agrupamentrs das plantas em 1951 eram significantemente diferentes entre 
si. Tais agrupamentos foram válidos para tôdas as épocas, com exceção de 1947, quando as plantas ainda se encontravam no período formativo. 2) A pesquisa florestal, neste caso, tornase suficientemente exáta, com áreas próximas de $200 \mathrm{~m} 2$ por repetição, contando sempre com "stands" de 25 a 30 exemplares. 3) Muito antes de atingir o limite considerado para o fim da idade nova, a distinção do comportamento dos diversos grupos era muito nítida. Em decorrência desta última conclusão, nos estudos de progenie, ao cabo de um lapso de tempo variável por certo para as essências, será possível determinar, já na idade nova, com absoluta exatidão, as melhores linhagens. Tal conclusão é comprovada pelas correlações entre anos e seus acréscimos. 4) $\mathrm{O}$ agrupamento das plantas por altura, indicará estatisticamente as diferentes classes de árvores, quais sejam: dominantes, codominantes, intermediárias e dominadas. 5) Como consequência prática do estudo do crescimento (pela delimitação das idades) sobressairão as épocas dos desbastes e de exploração dos maciços, bem como da ocasião, a partir da qual a matriz se encontra fisiologicamente apta a fornecer sementes. 
